\title{
The extraordinary botanical diversity of inselbergs in Madagascar
}

\author{
Marina N. Rabarimanarivo, Brigitte Ramandimbisoa, \\ Nivo H. Rakotoarivelo, Peter B. Phillipson, Sylvie Andriambololonera, \\ Martin W. Callmander \& Stefan Porembski
}

\begin{abstract}
RABARIMANARIVO, M.N., B. RAMANDIMBISOA, N.H. RAKOTOARIVELO, P.B. PHILLIPSON, S. ANDRIAMBOLOLONERA, M.W. CALLMANDER \& S. POREMBSKI (2019). The extraordinary botanical diversity of inselbergs in Madagascar. Candollea 74: 65-84. In English, English and French abstracts. DOI: http://dx.doi.org/10.15553/c2019v741a8

Inselbergs are isolated mountains, mainly granitic or gneissic rock outcrops rising abruptly above surrounding plains. Malagasy inselbergs are often dome-shaped and occur in varying degrees of isolation, but they sometimes form inselberg landscapes, which comprise dozens of individual outcrops. Despite being typical landscape features on Madagascar's high plateau, little data are available on their detailed plant cover. Recent extensive fieldwork, which was conducted between 2010 and 2014, mainly on the central plateau, has resulted in a better knowledge about the floristic composition and habitats of Malagasy inselbergs. The most speciose vascular plant genera were Cynorkis Thouars (18), Cyperus L. (15) and Euphorbia L. (14). Malagasy inselbergs are centres of diversity for succulents (notably species of the genera Aloe L., Euphorbia and Kalanchoe Adans.), carnivorous plants (species of Drosera L. and Utricularia L.) and resurrection plants (notably species of Xerophyta Juss.). The most speciose habitat types were ephemeral flush vegetation and monocotyledonous mats. The latter habitat supports a large number of succulents and resurrection plants. In total 724 taxa out of 338 genera and 107 families have been recorded. Moreover, the variability in floristic composition between different regions is remarkable. Detrimental human impacts include quarrying, grazing, fire and the collection of plants for ornamental purposes (species of Pachypodium Lindl. and Orchidaceae) and as medicine (species of Aloe, Drosera madagascariensis DC., Myrothamnus moschatus (Baill.) Baill.). For the first time, recommendations are made for the conservation of Malagasy inselbergs.
\end{abstract}

\footnotetext{
Addresses of the authors:

MNR, BR, NHR, SA: Missouri Botanical Garden, P.O. Box 3391, Antananarivo 101, Madagascar. E-mail: marina.rabarimanarivo@mobot-mg.org

PBP: Missouri Botanical Garden, 4344 Shaw Blvd., St. Louis, Missouri 63110, U.S.A. and Institut de Systématique,

Évolution, et Biodiversité (ISYEB), Muséum National d'Histoire Naturelle/Centre National de la Recherche Scientifique/

Sorbonne Universités/École Pratique des Hautes Études, C.P. 39, 57 rue Cuvier, 75005 Paris, France.

MWC: Conservatoire et Jardin botaniques de la Ville de Genève, ch. de l'Impératrice 1, C.P. 71, 1292 Chambésy, Switzerland.

SP: University of Rostock, Institute of Biosciences, Department of Botany, Wismarsche Str. 8, D-18051 Rostock, Germany.
}

Submitted on February 1, 2018. Accepted on February 22, 2019.

First published online on March 28, 2019. 


\section{Résumé}

RABARIMANARIVO, M.N., B. RAMANDIMBISOA, N.H. RAKOTOARIVELO, P.B. PHILLIPSON, S. ANDRIAMBOLOLONERA, M.W. CALLMANDER \& S. POREMBSKI (2019). L' extraordinaire diversité botanique des inselbergs de Madagascar. Candollea 74: 65-84. En anglais, résumés anglais et français. DOI: http://dx.doi.org/10.15553/c2019v741a8

Les inselbergs se définissent comme des affleurements rocheux isolés composés principalement de granite et de gneiss, couverts d'une végétation qui se démarque nettement de celles aux alentours. Les inselbergs malgaches ont souvent une forme de dôme et se rencontrent dans différents degrés d'isolement, présentant parfois des paysages d'inselbergs qui comprennent des douzaines d'affleurements individuels. Bien que constituant des éléments typiques et fréquents de paysage des Hauts-Plateaux de Madagascar, peu de données sur les détails de leur couverture végétale sont disponibles. Un récent travail de terrain extensif, principalement dans le plateau central, a permis d'obtenir une meilleure connaissance de la composition floristique et des habitats des inselbergs malgaches. Les genres possédant le plus grand nombre d'espèces incluent Cynorkis Thouars (18), Cyperus L. (15) et Euphorbia L. (14). Les inselbergs malgaches forment des centres de diversité pour les plantes succulentes (notamment les espèces d'Aloe L., Euphorbia et Kalanchoe Ands.), les plantes carnivores (les espèces de Drosera L. et Utricularia L.) et les plantes reviviscentes (notamment les espèces de Xerophyta Juss.). Les types d'habitats les plus riches en espèces sont les prairies marécageuses temporaires et les matelas ou tapis de monocotylédones. Ce dernier habitat comporte un grand nombre de plantes succulentes et de plantes reviviscentes. Un total de 724 taxons comprenant 338 genres et 107 familles ont été recensés. En outre, la variabilité dans la composition floristique entre inselbergs de différentes régions est remarquable. Les activités anthropiques ont des impacts très nuisibles sur l'intégrité écologique des inselbergs comme l'exploitation des carrières, le pâturage, le feu et la récolte des plantes à des fins ornementales (espèces de Pachypodium Lindl. et Orchidaceae) et médicinales (espèces d'Aloe, Drosera madagascariensis DC. ou Myrothamnus moschatus (Baill.) Baill.). Des recommandations détaillées sont publiées, pour la première fois, en vue de la conservation des inselbergs malgaches.

\section{Keywords}

Inselbergs - Madagascar - Conservation - Endemics - Medicinal plants - Resurrection plants - Succulents 


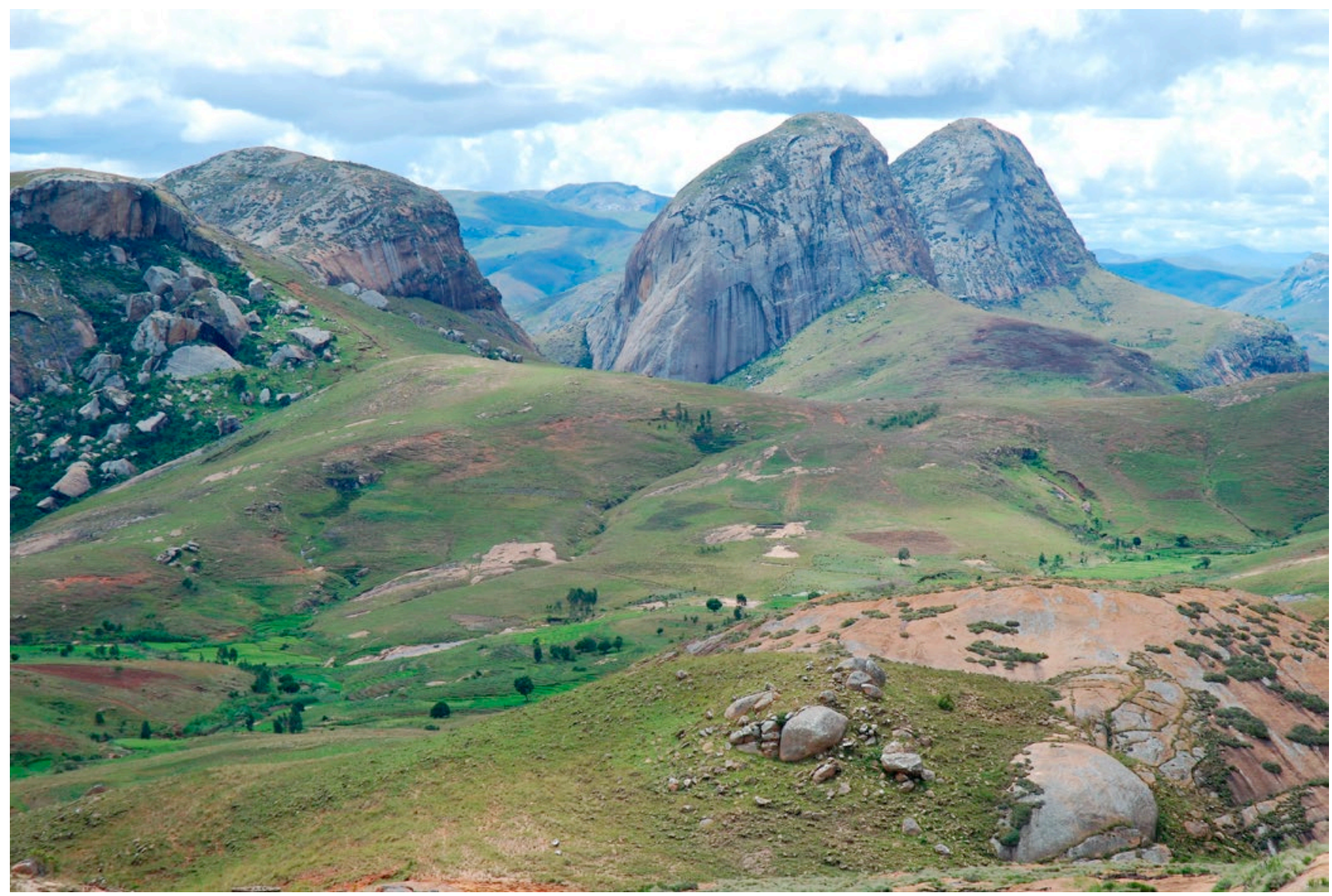

Fig. 1. - Inselberg landscape, near Ambalavao.

[Photo: S. Porembski]

\section{Introduction}

The vascular plant flora of Madagascar comprises c. 11,220 known species of which approximately $85 \%$ are endemic but, this does not include the estimated c. 1,900 undescribed endemic species (CAllmander et al., 2011). This richness has long attracted the interest of botanists and ecologists alike. Up to now, detailed floristic inventories have largely been concentrated on different types of forest, whereas vegetation of azonal habitats, such as those of inselbergs, have been rather neglected.

Inselbergs are isolated mountains, mostly granitic and gneissic outcrops that emerge more or less abruptly above the surrounding plains. They form ancient landscape features dating dozens of millions of years that are stable and widespread in both tropical and temperate zones (for overview see Porembski \& Barthlott, 2000). Due to their typically harsh environmental conditions, such as lack of soil and high temperatures, inselbergs are characterized by distinctive vegetation types and plant communities which usually differ significantly from those of surrounding areas.
In Madagascar, inselbergs occur in various parts of the island, but they are largely absent from the sedimentary plains of the west. Inselbergs are most frequent on Madagascar's high central plateau, the "Haut-Plateau", where they are common and sometimes have a dominant role in the landscape, either as solitary outcrops or as an inselberg landscape. Here, the extensive reworking of the crystalline basement, has given rise to a complex mix of hills and valleys, with numerous outcropping peaks made up of rocks such as quartz and granite or gneiss (Battistini \& Hoerner, 1986), for example near Ambalavao, south of Fianarantsoa (Fig. 1). Historically, the inselbergs of the central plateau have been of particular strategic importance to the Malagasy people, and indeed Antananarivo, the country's capital, has a large granite inselberg at its centre (Fig. 2).

Today, inselbergs offer a potential for tourism (e.g. for rock climbing), but remarkably, given their importance, the flora and vegetation of inselbergs are only superficially known. Prior to our study, only fragmentary data were available (e.g. RAuH, 1973; Fischer \& Theisen, 2000). Nevertheless, these data already suggested that Malagasy inselbergs are outstandingly 


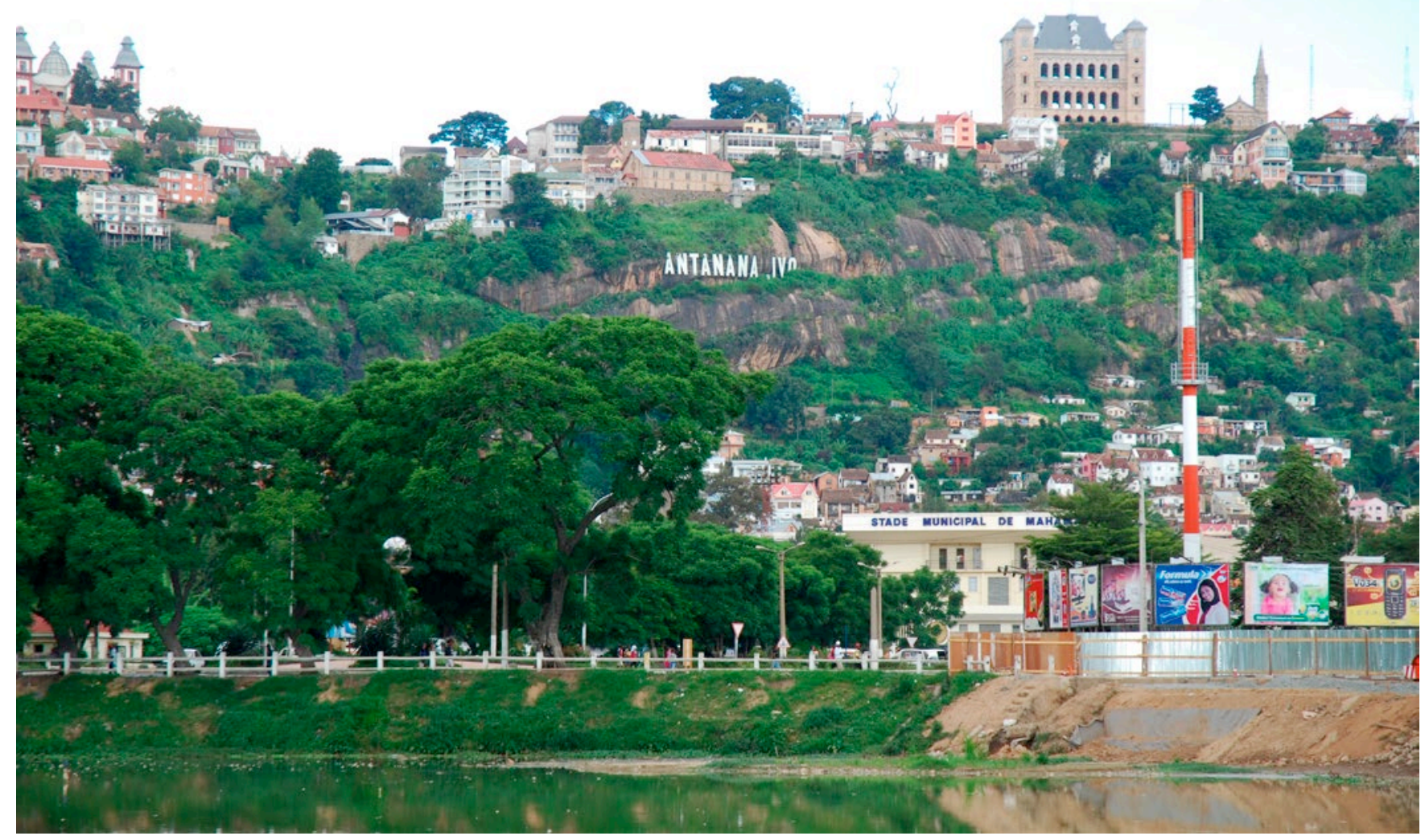

Fig. 2. - Inselberg in the capital Antananarivo with the "Palais de la Reine".

[Photo: S. Porembski]

rich in locally endemic species and possess more habitat specialists than similar habitats in most other tropical regions.

In order to improve our botanical knowledge of inselbergs in Madagascar, we conducted a series of expeditions to a representative selection of inselbergs on the central plateau. During these expeditions, we collected vascular plant specimens, and recorded observations on the status of the vegetation and the exploitation of inselbergs by the local people, documenting our observations photographically. Collected specimens were identified in the relevant herbaria, often in consultation with specialists. The results of this work will provide the much-needed information necessary to inform conservation management activities for the sites visited, and will contribute towards a comprehensive checklist of the Malagasy inselberg flora, to be delivered through the Catalogue of the Plants of Madagascar (Madagascar Catalogue, 2019), which can be consulted for additional information about the species recorded.

\section{Material and methods}

The majority of the fieldwork was carried out during the wet season: in March 2010 - during the devastating cyclone "Hubert", November and December 2010 and March 2011, 2012, 2013 and 2014, with additional observations being made during the dry season in May and June 2010.

The selection of inselbergs to be included in the study took into account various considerations, including: accessibility, relative intactness and sites known to be under-collected. The latter resulted from a preliminary survey of inselbergs based on information in relevant literature and from herbarium records, and also resulted in an initial vascular plant checklist. On each inselberg, all typical habitat types were inspected, the species present were noted and representative specimens were collected. Each specimen was georeferenced, photographed in situ and accompanied by descriptive data on its habitat. Dominant species in each habitat type and notable species absences were also recorded, together with signs of anthropogenic impacts. Furthermore, local vernacular names for the plants provided by local informants were recorded, as well as their local uses. 
A total of 35 inselbergs were visited (Table 1) on the subhumid Central Plateau and in the eastern and southern rainforest regions (Fig. 3). More than 2,100 herbarium specimens were collected. These have been deposited at TAN, and in most cases, when sufficient material was available, duplicate material has been deposited at $\mathrm{MO}$ and $\mathrm{P}$ and sent to experts in various plant groups at other institutions. All collected specimen data were entered into TROPICOs (2019) and incorporated into the Catalogue of the Plants of Madagascar project (Madagascar Catalogue, 2019), where they are publicly accessible. The checklist presented in this article (Appendix 1) includes only taxa collected during our field investigations which have IUCN Red List threat assessments. For a complete checklist please consult the Madagascar Catalogue - Inselberg flora website [http://www.tropicos.org/projectwebportal. aspx?pagename=Inselberg_Flora\&projectid=17].

\section{Results}

Nearly all the inselbergs visited belonged to the Bornhardttype (Twidale, 1981), most of which have a dome-shaped appearance with steeply sloping sides, but some inselbergs in the drier southern regions, i.e. Ankily, Vohidava and Parapaky, have stratified rock structure (for descriptive terms see Battistini \& Hoerner, 1986). Most of the inselbergs investigated were completely surrounded by agricultural land - mostly rice paddies, corn or cassava fields, and savoka grasslands - sometimes severely degraded due to excessive grazing and frequent burning. Very few were surrounded by forest.

On a broad geographical scale only a rather limited set of habitat types can be distinguished on inselbergs. The different habitats recognised are based mainly on ecological criteria and the physiognomic features of the plants present, notably the presence or absence of therophytes, perennial poikilohydrics and succulents (see Porembski et al., 2000). The habitats present at each site visited were identified and recorded. All habitat types characteristic for tropical inselbergs were encountered on all of the inselbergs studied. However, in contrast to other tropical regions, associated forest was only seen at a single site - the community-run Anja Park near Ambalavao, where a fringing sclerophyllous forest with a dense canopy and many lianas was present in ravines. Sclerophyllous Tapia woodland (characterized by Uapaca bojeri Baill. and Sarcolaenaceae species) was observed at "Bonnet du Pape" (south of Ambalavao) (Fig. 3: no 26; Fig. 6D), an inselberg in exceptionally good condition. A brief description of the most typical floristic and physiognomic elements of the inselbergs studied is given below, in relation to the different habitats.

\section{Habitat types}

\section{Cryptogamic crusts and drainage channels}

Although not studied in detail, preliminary observations have shown that crustose lichens form dense crusts on exposed rocky slopes and boulders with cyanobacteria, and they are responsible for characteristic rock coloration. Epilithic fruticose lichens, species of Usnea Dill. and a diversity of cyanobacteria were also generally present. On the Central Plateau, only "lichen-inselbergs" (i.e. with the lichens dominant on exposed rock) occur, whereas "cyanobacteria-inselbergs" (i.e. with cyanobacteria dominating) occur in the humid east.

\section{Epilithic vascular plants}

Occasionally succulents were observed that were growing directly on exposed rock. Most frequent were species of Aloe L. (e.g. A. capitata Baker, $A$. deltoideodonta Baker, $A$. divaricata A. Berger), Pachypodium Lindl. (e.g. P. densiflorum Baker, P. horombense Poiss.), Euphorbia L. (e.g. E. alluaudii Drake, $E$. didiereoides Denis ex Leandri, and E. horombensis Ursch \& Leandri: Fig. 4) and Orchidaceae of various genera (e.g. Angraecum pseudofilicornu H. Perrier, Oeceoclades beravensis (Rchb. f.) R. Bone \& Buerki and Sobennikoffia humbertiana H. Perrier). Some ferns were also be found on exposed rock (e.g. Pleopeltis macrocarpa (Bory ex Willd.) Kaulf.).

\section{Crevices and boulders}

Depending on their width and depth, crevices and fissures offer rooting opportunities for a variety of perennial species of varying life forms including herbs (e.g. Peperomia blanda (Jacq.) Kunth and some Orchidaceae), lianas (incl. Cyphostemma horombense Desc., Paederia farinosa (Baker) Puff), as well as shrubs and trees (e.g. Ficus menabeensis H. Perrier, Entada chrysostachys (Benth.) Drake, various species of Senecio L., and Vepris pilosa (Baker) I. Verd.). Most of shrub and tree species encountered are not restricted to inselbergs but they also occur in vegetation surrounding the inselbergs. For example, species of Sarcolaenaceae, typical species of Tapia woodland, are frequently observed and collected on inselbergs. Species of Aloe, Cyanotis D. Don and Euphorbia as well as a number of grass species were also found frequently in this habitat, and ferns are usually present as well, with the desiccation-tolerant species such as Actiniopteris dimorpha Pic. Serm. (Fig. 5A), certain species of Asplenium L., Pellaea dura (Willd.) Hook., P. pectiniformis Baker and Cheilanthes viridis (Forssk.) Sw. being common elements. Under more humid climatic conditions, dense cushions of mosses (e.g. species of Leucobryum Hambe) occur in crevices and fissures. The invasive weed Furcraea foetida (L.) Haw. (Asparagaceae) occasionally forms dense colonies on certain inselbergs like Tangorika (Fig. 6A; Fig. 3: no 25). 


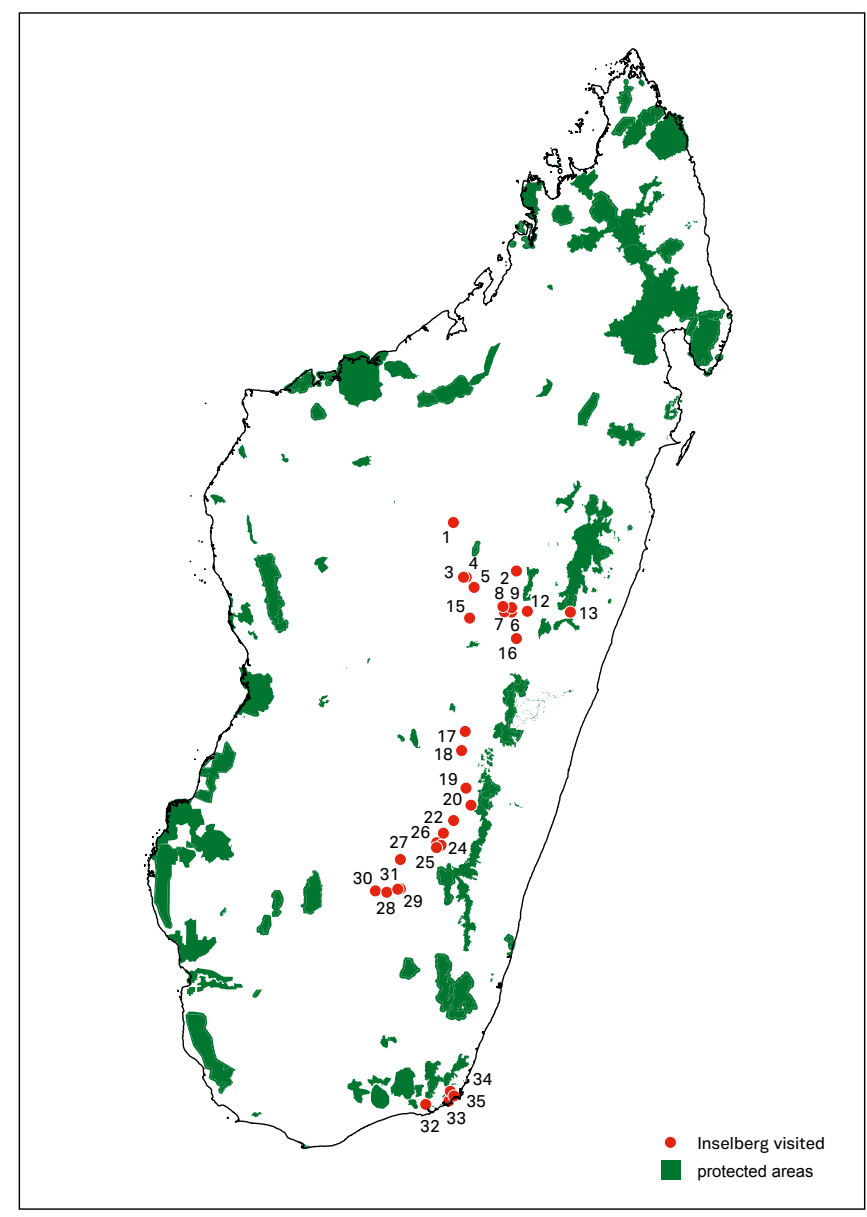

Fig. 3. - Map of the inselbergs visited (numbers refer to Table 1) in Madagascar (mostly around Antananarivo and Moramanga, the centre South and Taolagnaro).

\section{Rock pools and shallow depressions}

Few rock pools were recorded, most were less than $1 \mathrm{~m}^{2}$ in area and no more than $10 \mathrm{~cm}$ in depth at the times of the visits. No inselberg-specific higher plants were recorded. As noted by Fischer \& Theisen (2000) rock pools generally lack ephemeral species in Madagascar. Similar to rock pools, shallow depressions were rarely observed, and were usually devoid of plant cover, but occasionally species of Cyanotis were recorded.

\section{Monocotyledonous mats}

These grasslike mats change their physiognomic appearance according to seasonality (Fig. 6B). Most mat-forming species are desiccation-tolerant. The most typical mat-forming species is the sedge Coleochloa setifera (Ridl.) Gilly (Cyperaceae) which was seen to have colonized very steeply inclined rocky slopes (Fig. 6C). Typically, individual mats were several square meters in extent, with this single species often covering more than $75 \%$ of the ground. The C. setifera mats are colonized by many perennial species whereas annuals are rare. Typical co-occurring species were other resurrection plants (e.g. Myrothamnus moschatus (Baill.) Baill., poikilohydric species of Selaginella P. Beauv. (e.g. S. echinata Baker, S. helicoclada Alston), Styppeiochloa hitchcockii (A. Camus) Cope and species of Xerophyta Juss. whose trunks can reach a maximum height of $1.5 \mathrm{~m}$. Succulent plants were also found. On some inselbergs, Coleochloa setifera was not dominant, notably at Lohavohitra (Fig. 3: $\mathrm{n}^{\circ}$ 4) and around Fort-Dauphin (e.g. Ambondrondria: Fig. 3: no 34). Remarkably, Coleochloa setifera was absent from certain inselbergs visited in the humid eastern areas (e.g. Andriambavibe, Fig. 3: $n^{\circ} 21$ ). It is not clear whether particular climatic factors are responsible for its absence. Styppeiochloa bitchcockii was seen to be the dominant mat-former, or codominant with Coleochloa setifera, in many parts of Madagascar. This desiccation-tolerant grass frequently forms extensive mats on inselbergs near Antananarivo and in Central Madagascar. Hitherto the widespread occurrence of this species on Malagasy inselbergs has been largely overlooked.

Several species of Xerophyta are likewise widespread as mat-formers (Fig. 5B), they are desiccation-tolerant shrubs that are poikilochlorophyllous. The Xerophyta mats mainly occur on less steeply inclined slopes and are also colonized by a considerable number of perennials. Epiphytic Orchidaceae are common on the trunks of the larger species.

\section{Ephemeral flush vegetation}

Ephemeral flush vegetation (EFV) has a meadow-like physiognomy and shows a well expressed seasonality between rainy and dry season. This plant community develops on gently inclined rocky slopes where water constantly seeps during the rainy season and exceptionally even in the dry season. Dominant species are mostly small, shortlived herbs that form a dense vegetation layer over shallow, nutrient poor substrate. Carnivorous plants are common, i.e. Droseraceae: Drosera burkeana Planch., D. indica L., D. madagascariensis DC. (Fig. 5C) and D. natalensis Diels, as well as Lentibulariaceae: with numerous species of Utricularia L. (Fig. 5D) and Orchidaceae, e.g. Cynorkis uniflora Lindl. and species of Habenaria Willd. Cyperaceae and Poaceae are the dominant families, and other characteristic families include Campanulaceae, Eriocaulaceae, Gentianaceae, Linderniaceae, Orobanchaceae and Xyridaceae. Most speciose genus in this habitat was Exacum L. with 12 species. In certain rare cases (e.g. at Lohavohitra, Fig. 3: $n^{\circ}$ 4) where water is continuously seeping throughout the year, the percentage of perennials in $\mathrm{EFV}$ is relatively high. Under these circumstances, the prostrate Lycopodiella affinis (Bory) Pic. Serm. was recorded. In addition to higher plants, cyanobacteria and mosses cover the ground to various extents. 
Table 1. - Localities of the 35 inselbergs studied and general notes on their condition (Inselberg numbers refer to Fig. 3; Square brackets in the inselbergs names refer to name of nearest village when the name of the inselberg is unknown).

\begin{tabular}{|c|c|c|c|c|c|c|}
\hline $\mathrm{n}^{\circ}$ & Inselberg name & Region & Province & Locality & Coordinates & Inselberg condition \\
\hline 1 & Marotsipohy & $\begin{array}{l}\text { Analamanga/ } \\
\text { Betsiboka }\end{array}$ & $\begin{array}{l}\text { Antananarivo/ } \\
\text { Mahajanga }\end{array}$ & Mahatsinjo & $17^{\circ} 49^{\prime} 48^{\prime \prime S} 47^{\circ} 01^{\prime} 34^{\prime \prime} \mathrm{E}$ & Degraded (fire) \\
\hline 2 & Ambatovoloina & Analamanga & Antananarivo & Sambaina & $18^{\circ} 30^{\prime} 37^{\prime \prime S} 47^{\circ} 09^{\prime} 03^{\prime \prime} \mathrm{E}$ & Good \\
\hline 3 & [Bevomanga] & Analamanga & Antananarivo & Bevomanga & $18^{\circ} 30^{\prime} 44^{\prime \prime S} 47^{\circ} 11^{\prime} 04^{\prime \prime} \mathrm{E}$ & Very degraded (fire, quarry) \\
\hline 4 & Lohavohitra & Analamanga & Antananarivo & Andranovelona & $18^{\circ} 38^{\prime} 05^{\prime \prime S} 47^{\circ} 16^{\prime} 58^{\prime \prime} \mathrm{E}$ & Degraded \\
\hline 5 & Andrakitsikitsika & Analamanga & Antananarivo & Ambatomanga & 18०56'31"S 4741'36"E & Degraded \\
\hline 6 & Iharamalaza & Analamanga & Antananarivo & Ambohimiadana & 19०16'19"S 4748'18"E & Good \\
\hline 7 & Andomotra & Analamanga & Antananarivo & Anjozorobe & $18^{\circ} 25^{\prime} 55^{\prime \prime S} 47^{\circ} 48^{\prime} 12^{\prime \prime} \mathrm{E}$ & Degraded \\
\hline 8 & [Ambanitsena] & Analamanga & Antananarivo & Ambanitsena & $18^{\circ} 52^{\prime} 32^{\prime \prime S} 47^{\circ} 41^{\prime} 33^{\prime \prime E}$ & Very degraded \\
\hline 9 & [Maharidaza] & Analamanga & Antananarivo & Maharidaza & $18^{\circ} 53^{\prime} 31^{\prime \prime S} 47^{\circ} 43^{\prime} 40^{\prime \prime} \mathrm{E}$ & Degraded \\
\hline 10 & Angavokely & Analamanga & Antananarivo & Carion & $18^{\circ} 55^{\prime} 17^{\prime \prime S} 47^{\circ} 44^{\prime} 19^{\prime \prime} \mathrm{E}$ & Degraded \\
\hline 11 & Angavobe & Analamanga & Antananarivo & Carion & $18^{\circ} 55^{\prime} 35^{\prime \prime S} 47^{\circ} 45^{\prime} 05^{\prime \prime} E$ & Good \\
\hline 12 & Vatolava & Analamanga & Antananarivo & Carion & $18^{\circ} 55^{\prime} 32^{\prime \prime S} 47^{\circ} 44^{\prime} 01^{\prime \prime E}$ & Good \\
\hline 13 & Ambatomisondrotra & Analamanga & Antananarivo & Carion & $18^{\circ} 55^{\prime} 22^{\prime \prime S} 47^{\circ} 44^{\prime} 23^{\prime \prime} \mathrm{E}$ & Good \\
\hline 14 & Sambaina & Analamanga & Antananarivo & Marozevo & $18^{\circ} 55^{\prime} 56^{\prime \prime S} 47^{\circ} 56^{\prime} 35^{\prime \prime} \mathrm{E}$ & Very degraded \\
\hline 15 & [Andranomena] & Itasy & Antananarivo & $\begin{array}{l}\text { Andranomena } \\
\text { Arivonimamo }\end{array}$ & 1901'08"S 47¹3'32"E & Degraded \\
\hline 16 & Ambohitrinimasina & Amoron'i Mania & Fianarantsoa & Tsarasaotra & $20^{\circ} 25^{\prime} 26^{\prime \prime S} 47^{\circ} 10^{\prime} 18^{\prime \prime} \mathrm{E}$ & Good \\
\hline 17 & [Anjoman'Ankona] & Amoron'i Mania & Fianarantsoa & Anjoman'Akona & $20^{\circ} 39^{\prime} 47^{\prime \prime S} 47^{\circ} 07^{\prime} 47^{\prime \prime} \mathrm{E}$ & Good \\
\hline 18 & Ilanjana & Haute Matsiatra & Fianarantsoa & Ambohimahasoa & $21^{\circ} 07^{\prime} 38^{\prime \prime S} 47^{\circ} 10^{\prime} 46^{\prime \prime} \mathrm{E}$ & Very degraded \\
\hline 19 & Ambatomisoratra & Haute Matsiatra & Fianarantsoa & $\begin{array}{l}\text { Alakamisy } \\
\text { Ambohimaha }\end{array}$ & $21^{\circ} 20^{\prime} 21^{\prime \prime S} 47^{\circ} 14^{\prime} 35^{\prime \prime} \mathrm{E}$ & Very degraded \\
\hline 20 & Langela & Haute Matsiatra & Fianarantsoa & Soaindrana & 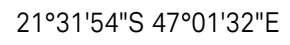 & Good \\
\hline 21 & [Andrainjato] & Haute Matsiatra & Fianarantsoa & Ambalavao & $21^{\circ} 41^{\prime} 14^{\prime \prime S} 46^{\circ} 53^{\prime} 54^{\prime \prime} \mathrm{E}$ & Degraded \\
\hline 22 & Ambalalova & Haute Matsiatra & Fianarantsoa & Anja & $21^{\circ} 50^{\prime} 08^{\prime \prime S} 46^{\circ} 50^{\prime} 14^{\prime \prime} \mathrm{E}$ & Good (some habitats degraded) \\
\hline 23 & Vohitsanavo (west side) & Haute Matsiatra & Fianarantsoa & Anja & $21^{\circ} 51^{\prime} 10^{\prime \prime S} 46^{\circ} 50^{\prime} 03^{\prime \prime} \mathrm{E}$ & Good \\
\hline 24 & Amboalandy (east side) & Haute Matsiatra & Fianarantsoa & Anja & $21^{\circ} 51^{\prime} 08^{\prime \prime S} 46^{\circ} 50^{\prime} 45^{\prime \prime} \mathrm{E}$ & Good \\
\hline 25 & Tangorika (south side) & Haute Matsiatra & Fianarantsoa & Anja & $21^{\circ} 52^{\prime} 25^{\prime \prime S} 46^{\circ} 49^{\prime} 38^{\prime \prime} \mathrm{E}$ & Good \\
\hline 26 & Brioche or Bonnet du Pape & Ihorombe & Fianarantsoa & Voatavo & $22^{\circ} 00^{\prime} 53^{\prime \prime S} 46^{\circ} 21^{\prime} 59^{\prime \prime} \mathrm{E}$ & Good \\
\hline 27 & Ambohibola & Ihorombe & Fianarantsoa & Ihosy & $22^{\circ} 22^{\prime} 40^{\prime \prime S} 46^{\circ} 21^{\prime} 56^{\prime \prime} \mathrm{E}$ & Good \\
\hline 28 & Andreketampanano & Ihorombe & Fianarantsoa & Ihosy & $22^{\circ} 23^{\prime} 06^{\prime \prime} \mathrm{S} 46^{\circ} 20^{\prime} 40^{\prime \prime} \mathrm{E}$ & Good \\
\hline 29 & Vohidava & Ihorombe & Fianarantsoa & Ihosy & $22^{\circ} 25^{\prime} 17^{\prime \prime S} 46^{\circ} 12^{\prime} 04^{\prime \prime} \mathrm{E}$ & Good \\
\hline 30 & [Ankily] & Ihorombe & Fianarantsoa & Ihosy & $22^{\circ} 24^{\prime} 13^{\prime \prime S} 46^{\circ} 03^{\prime} 24^{\prime \prime} \mathrm{E}$ & Degraded (fire, quarry) \\
\hline 31 & Andriambavimbe & Alaotra-Mangoro & Toamasina & Anevoka & $18^{\circ} 56^{\prime} 26^{\prime \prime S} 48^{\circ} 28^{\prime} 14^{\prime \prime} \mathrm{E}$ & Degraded \\
\hline 32 & Besivy & Anosy & Toliara & Taolagnaro & $25^{\circ} 03^{\prime} 21^{\prime \prime S} 46^{\circ} 40^{\prime} 29^{\prime \prime} \mathrm{E}$ & Degraded \\
\hline 33 & Pic Saint Louis & Anosy & Toliara & Taolagnaro & $25^{\circ} 00^{\prime} 29^{\prime \prime S} 46^{\circ} 57^{\prime} 55^{\prime \prime} \mathrm{E}$ & Good (some habitats degraded) \\
\hline 34 & Ambondrondria & Anosy & Toliara & Taolagnaro & $24^{\circ} 53^{\prime} 38^{\prime \prime S} 46^{\circ} 58^{\prime} 58^{\prime \prime} \mathrm{E}$ & Degraded (fire) \\
\hline 35 & Ambalavato & Anosy & Toliara & Taolagnaro & $24^{\circ} 56^{\prime} 25^{\prime \prime S} 47^{\circ} 02^{\prime} 43^{\prime \prime} \mathrm{E}$ & Good \\
\hline
\end{tabular}


Table 2. - The ten most species-rich families recorded in the study.

\begin{tabular}{ll}
\hline Family & \# of taxa \\
\hline Orchidaceae & 87 \\
Cyperaceae & 45 \\
Rubiaceae & 42 \\
Asteraceae & 38 \\
Apocynaceae & 34 \\
Poaceae & 34 \\
Fabaceae & 28 \\
Asparagaceae & 27 \\
Euphorbiaceae & 25 \\
Lamiaceae & 21 \\
\hline
\end{tabular}

Table 3. - The ten most species-rich genera recorded in the study (genera with all recorded species endemic to Madagascar in bold print).

\begin{tabular}{ll}
\hline Genus & Total of taxa \\
\hline Cynorkis (Orchidaceae) & 18 \\
Cyperus (Cyperaceae) & 15 \\
Euphorbia (Euphorbiaceae) & 14 \\
Kalanchoe (Crassulaceae) & 14 \\
Aloe (Asphodelaceae) & 13 \\
Cynanchum (Apocynaceae) & 13 \\
Exacum (Gentianaceae) & 13 \\
Angraecum (Orchidaceae) & 12 \\
Senecio (Asteraceae) & 11 \\
Xerophyta (Velloziaceae) & 10
\end{tabular}

\section{Floristic and physiognomic composition}

Six hundred and twenty-seven taxa (627) have been identified to species level (or below) and 97 additional morphospecies have been identified, at least some of which are known to represent as yet undescribed species. In total 107 families and 338 genera are represented among these specimens. Sixty-seven percent $(67 \%)$ of the taxa are endemic to Madagascar (about a third of which are inselberg-endemics), $31 \%$ are native but not endemic to Madagascar and $2 \%$ are naturalized introductions (Fig. 7A).

Orchidaceae is by far the most speciose family (87 taxa), followed by Cyperaceae (45) and Rubiaceae (42), a further seven families are represented by more than 20 taxa (Table 2). The 381 taxa in these 10 families represent $48 \%$ of the total inselberg flora. Cynorkis Thouars (Orchidaceae) is the most speciose genus (18 taxa), followed by Cyperus L. (Cyperaceae)
(15 taxa), and with eight other genera with 10 or more taxa. The 133 taxa in these 10 genera represent $18 \%$ of the total inselberg flora, and in four of them all represented species are endemic to Madagascar, i.e. Aloe, Kalanchoe Adans., Senecio and Xerophyta (Table 3).

Some species were recorded on most of the inselbergs, notably: Antherotoma naudinii Hook. f., Coleochloa setifera, Cynanchum perrieri Choux, Hypoxis angustifolia Lam., Lysimachia rubricaulis (Duby) U. Manns \& Anderb., Nematostylis anthophylla (A. Rich.) Baill., Tetradenia fruticosa Benth. and Xerophyta pectinata Baker. Other species were highly localized, occurring only on certain inselbergs, such as Aloe haworthioides Baker (Fig. 8A) (known from inselbergs around Ihorombe and Haute Matsiatra regions, only recorded during our study from Anja Park, at Vohitsanavo, Fig. 3: $\mathrm{n}^{\circ} 23$ ), A. perrieri Reynolds (known from inselbergs around Zazafotsy, Fandana and Ihosy, only recorded during our study from "Bonnet du Pape", Fig. 3: n 26; Fig. 6D), Linderniella horombensis (Eb. Fisch.) Eb. Fisch. et al. (recorded from inselbergs around Ambalavao, Fandana and Ihosy during this study, Fig. 3: $n^{\circ} 21,26,29$ ), Pachypodium horombense (only recorded from inselbergs around Ihosy during our study, Fig. 3: 27-29; Fig. 8B).

Another group of species, e.g. Myrothamnus moschatus, have a widespread distribution on inselbergs in Madagascar, but their presence on a given inselberg is unpredictable. Others are regionally localized, but not always present, e.g. Capitanopsis oreophila (Guillaumin) Mwanyambo et al. from the Horombe plateau, only recorded from Anja Park, Ambalalova, Vohitsanavo, Amboalandy, Tangorika, and la Brioche. Remarkably, no species was present on all inselbergs studied whereas the number of rather localized species was relatively high.

Life form analysis shows herbaceous species as best represented (61\%), followed by shrubs (27\%), vines and lianas (7\%), while tree species represent only 5\% (Fig. 7B). Among the herbaceous species, the most widespread species is the desiccation-tolerant Cyperaceae Coleochloa setifera. Desiccationtolerance is also found in other herbaceous genera, such as: Lindernia All., Linderniella Eb. Fisch. et al. and Streptocarpus Lindl., and in ferns such as: Asplenium, Cheilanthes Sw., Doryopteris J. Sm. and Selaginella. We estimate that in total more than 40 desiccation-tolerant vascular plant species occur on Malagasy inselbergs, which is $14 \%$ of the estimated world total of c. 300 species desiccation-tolerant plants on rock outcrops (Porembski \& Barthlott, 2000).

On all inselbergs studied, numerous leaf and stem succulent species have been recorded that preferentially occurred in monocotyledonous mats, crevices and more rarely as lithophytes. Among the genera that could be recorded more frequently were Aloe, Cynanchum L., Cyanotis, Euphorbia, Kalanchoe, Pachypodium, Rhipsalis Gaertn. and Senecio. In addition, a number of succulent orchids (e.g. Aerangis ellisii 


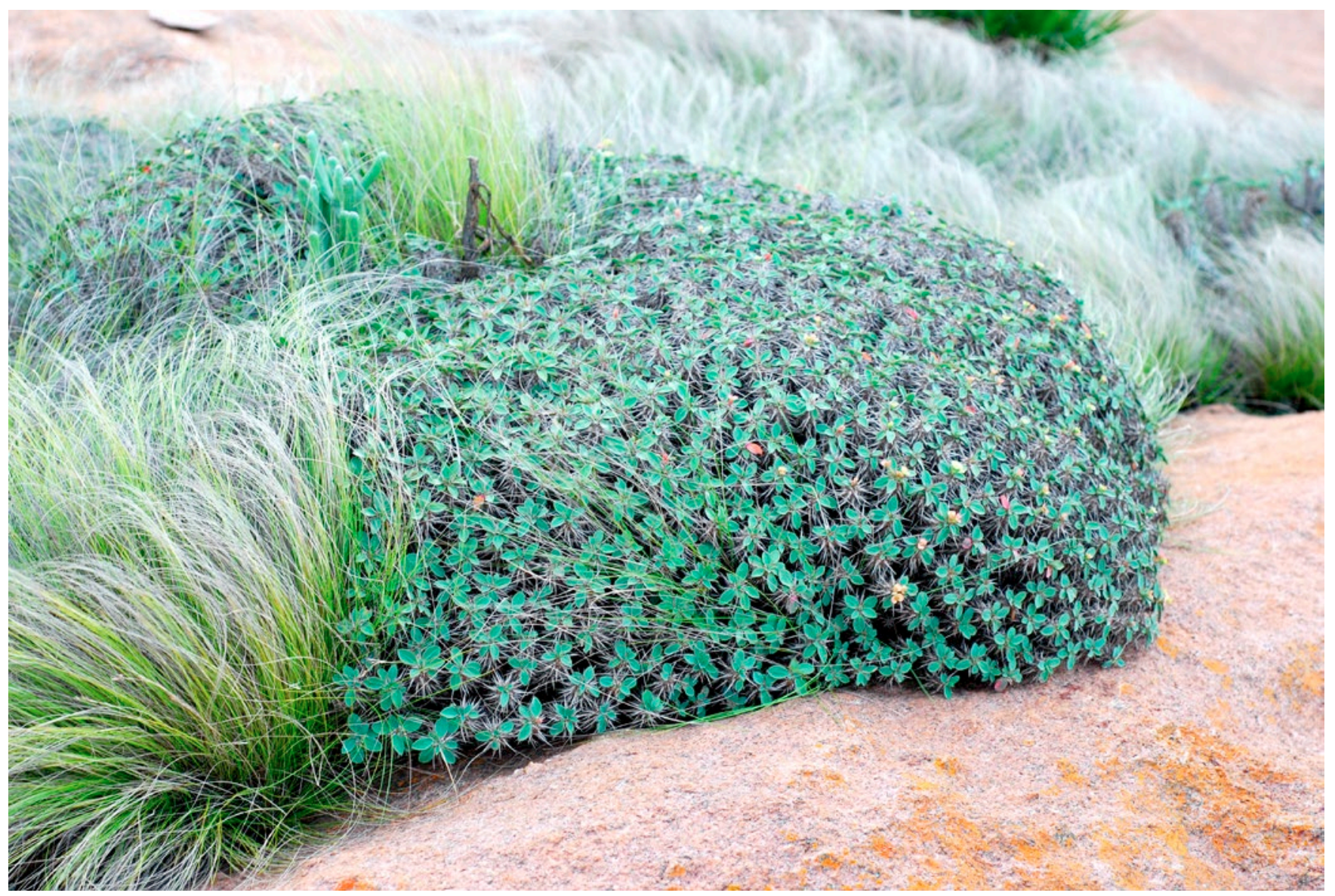

Fig. 4. - Euphorbia horombensis Ursch \& Leandri (Euphorbiaceae) a succulent on open rocks at Vohitsanavo inselberg, Anja Park (Fig. 3: no 23). [Razafindraibe et al. 278] [Photo: S. Porembski]

(B.S. Williams) Schltr., Angraecum pseudofilicornu, Oeceoclades calcarata (Schltr.) Garay \& P.Taylor, Sobennikoffia humbertiana) were present.

\section{Threats and Conservation}

Among the 627 taxa identified, just c. $28 \%$ (177) have been evaluated for the IUCN Red List following IUCN Red list Categories and Criteria (IUCN, 2012) by MBG-GSPM (the IUCN plant red listing authority in Madagascar). Among those 177 species assessed, 76 species $(43 \%)$ have a threatened status as Critically Endangered [CR] (4), Endangered [EN] (37) or Vulnerable [VU] (35) (see Appendix I for details). Certain families which include many inselberg specialists such as Asparagaceae, Asphodelaceae, Crassulaceae, and Velloziaceae have not yet had threat assessments conducted any of the species identified (but see Rakotoarisoa et al., 2014 for Aloe), nor have any of the inselberg pteridophytes. Undoubtedly, many of these are threatened, especially in cases of particularly rare, locally endemic species, such as Aloe haworthioides and A. perrieri which both have a limited distribution range. Genlisea margaretae Hutch., a carnivorous species that also occurs in East Africa (FIScher et al., 2000), is currently known only from one inselberg in Madagascar, representing a single location (sensu IUCN, 2012). The only locality for this species known to Bosser (1958), who superfluously described it a new species (Madagascar Catalogue, 2019), was destroyed as a viable habitat for the species through urbanization (RAUH, 1973). We visited the site and can confirm this, but found G. margaretae at another nearby site. Moreover, 125 species $(17 \%)$ of all taxa inventoried are registered in the list of restricted species for trade on CITES Appendices I and II (CITES, 2019), due to their horticultural interest. These are mainly Asphodelaceae, Euphorbiaceae and Orchidaceae, and illegal trade in many of them continues despite their CITES status (Newman, 2003; UNEP-WCMC, 2010; Willis, 2017).

\section{Discussion}

Despite our inadequate knowledge about Malagasy inselbergs, it is already clear that they are outstandingly rich in terms of both species diversity and endemicity. Remarkable examples of taxa showing a rich interspecific and/or infraspecific differenti- 
ation are to be found within certain genera, e.g. Aloe, Euphorbia and Xerophyta. The reasons for this high diversity in Madagascar are manifold, but two particularly important factors are the extremely large number of scattered outcrops and the high diversity of rock type (e.g. granitic, quartzitic, and calcareous). Furthermore, the existence of other azonal habitats such as white sand savannas which have probably promoted the evolution of particularly rich species-complexes within these genera in Madagascar. In many cases, modern taxonomic revisionary work, such as in some of the genera mentioned above, has served to reveal even higher levels of diversity and local endemism than had previously been documented.

Our results show that Malagasy inselbergs do not differ from other tropical regions regarding the habitat types. As for tropical African and Indian inselbergs, the EFV is the most species rich habitat (Porembski \& Watve, 2005). Remarkably speciose are monocotyledonous mats, this is mainly due to the presence of numerous desiccation-tolerant species and succulents (a "succulent paradise" sensu RAUH, 1995). Coleocbloa setifera is dominant in both Malagasy and East African monocotyledonous mats on inselbergs. This is probably the only case of an inselberg specific species that is shared between Africa and Madagascar.

Our results also show that in general the floristic composition of Malagasy inselbergs resembles those of East African inselbergs (Porembski, 1996; Seine et al., 2000). For certain genera, Malagasy inselbergs are particularly important centres of diversity; this is the case for Aloe, Cynanchum, Euphorbia, Exacum, Kalanchoe and Xerophyta. Despite the fact that only a relatively small number of Malagasy inselbergs have been investigated in detail, it is already apparent that their species richness is remarkably high. We assume that further exploration will increase the hitherto known number of species and that the species richness of Malagasy inselbergs will be shown to be among the highest in the world. The number of inselbergendemics in Madagascar is higher than in most other tropical regions, but can be compared with inselbergs in certain parts of East Africa (e.g. Zimbabwe, see SeIne et al., 1995) and South America (SE Brazil, S Venezuela, see Porembski et al., 1998; Gröger, 2000; Porembski, 2005; Gröger \& Huber, 2007) which also have high levels of endemism. The considerable degree of species turnover between individual inselbergs in Madagascar is possibly caused by the vicariant replacement of species within certain taxa, notably in the genus Euphorbia, but it is not clear whether this is due to limitations in their dispersal efficiency or other factors. In most other tropical regions, betadiversity of inselbergs is much lower. However, inselbergs in SE Brazil (e.g. Federal States of Rio de Janeiro, Espirito Santo) show a similar extent of species turnover.

It is possible that the long isolation and relative climatic stability have promoted the high rates of endemicity on Malagasy inselbergs. According to Iwamura et al. (2010),
Madagascar has had high levels of climatic stability (over 80\%) which means that the future predicted climatic conditions remain within the present climate profile of the ecoregion. This high climatic stability overlaps with the areas that are known for their high biodiversity. This may be highly relevant for long term conservation planning in the context of global climate change.

Despite the lack of detailed ecological data for azonal habitats in general, it can be stated that the number of species which are limited to inselbergs is considerably higher than the number of generalist species present. While almost all of the lithophytes and monocotyledonous mats species are habitat specialists, confined to rock outcrops, species found in EFV are more frequently habitat generalists that also occur in marshy places off inselbergs, notably certain Cyperaceae and Poaceae. The low species diversity in rock pools and their complete lack of habitat specialists is striking compared to inselbergs outside of Madagascar. This is all the more remarkable in the case of Lindernia, a genus including several rock pool specialists in tropical Africa, and which comprises nine species in Madagascar (six are endemic), but none are rock pool specialists.

The number of species that also occur on inselbergs outside Madagascar is low. Examples of species that are shared between continental African and Malagasy inselbergs include Drosera indica and Utricularia subulata L., which are both widespread outside Africa and Madagascar. The data that are currently available indicate that floristic relationship of inselbergs is strongest with Zambezian Region in eastern and southern Africa, doubtless due to their proximity. Examples include the genera Aloe, Anthospermum L., Exacum, Euphorbia, Lindernia, Myrothamnus Welw., Pachypodium, Styppeiochloa De Winter, and Xerophyta, which are all well-represented in the two regions, but by different species, while certain species occur in both regions (e.g. Coleochloa setifera and Genlisea margaretae). Relationship with West African inselbergs is weaker, but nevertheless some desiccation-tolerant matforming species, related to Coleochloa setifera (also belonging to the tribe Trilepideae), such as Afrotrilepis pilosa (Boeckeler) $\mathrm{J}$. Raynal and Microdracoides squamosus Hua occur in this part of the continent. Floristic links between Malagasy inselbergs and rock outcrops on the Arabian Peninsula can also be found through the occurrence of Aloe and Xerophyta at the southern tip of the Arabian Peninsula. It is interesting to note that certain genera which are absent from Malagasy inselbergs are typical elements of the vegetation of inselbergs elsewhere (mostly in tropical Africa), e.g. Burmannia L., Isoetes L. and Tripogon Roem. \& Schult. The absence of Isoetes is particularly remarkable, as this genus is widespread on tropical and temperate inselbergs, and includes numerous locally endemic species.

Most granite and gneiss inselbergs in Madagascar are located outside the national protected area network, 

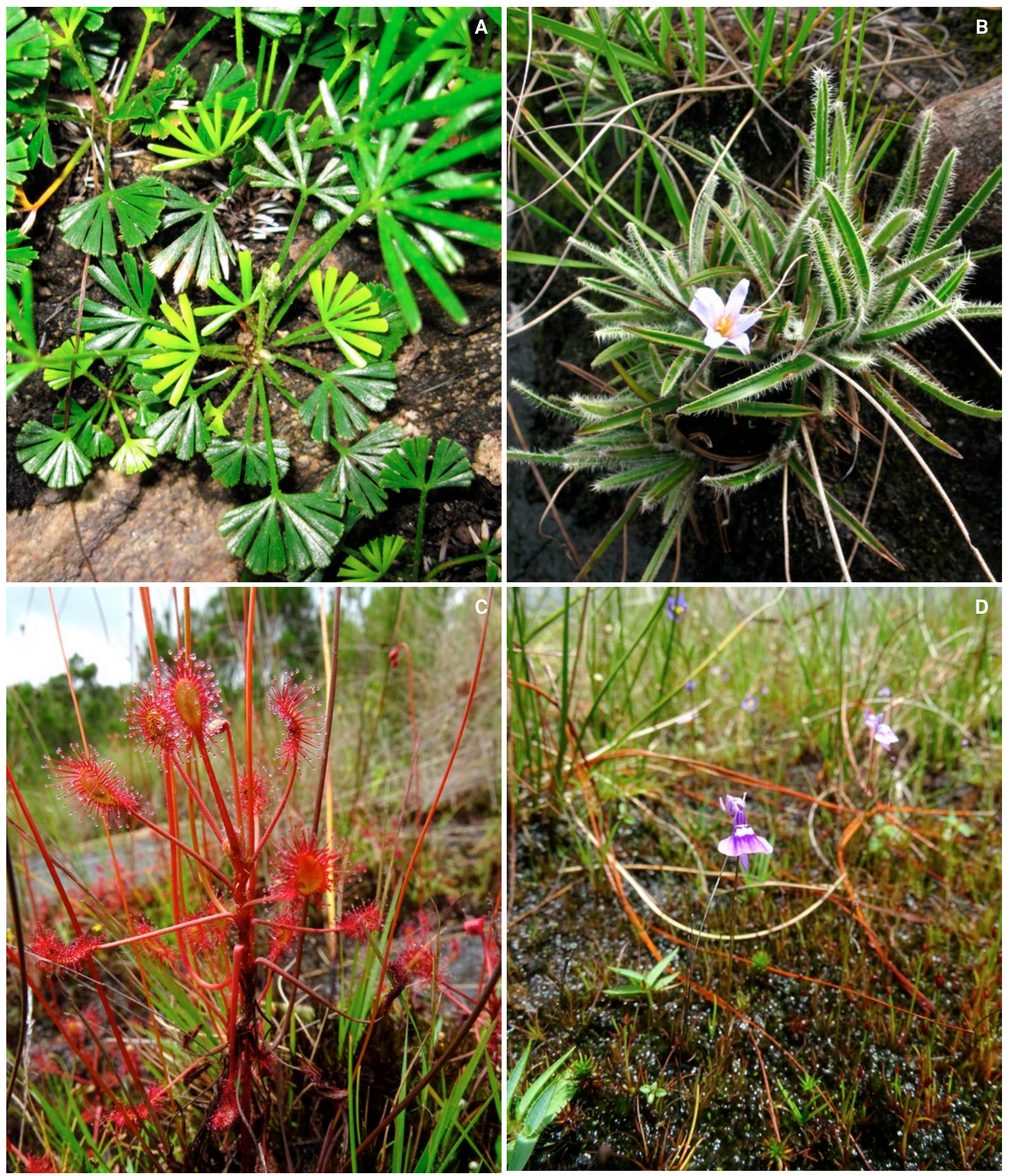

Fig. 5. - A. Actiniopteris dimorpha Pic. Serm. (Pteridaceae) a desiccation-tolerant species of fern at Vohidava, Ihosy; B. Xerophyta sp. (Velloziaceae) near Anjoman'Akona, south of Ambositra; C. Drosera madagascariensis DC. (Droseraceae); D. Utricularia sp. (Lentibulariaceae).

[A: Razafindraibe et al. 300; B: Rakotoarivelo et al. 287; C: Rabarimanarivo et al. 745; D: Rabarimanarivo et al. 705] [Photos: A: A. Ramahefaharivelo; B: N. Rakotoarivelo; C-D: S. Giebelmann] 

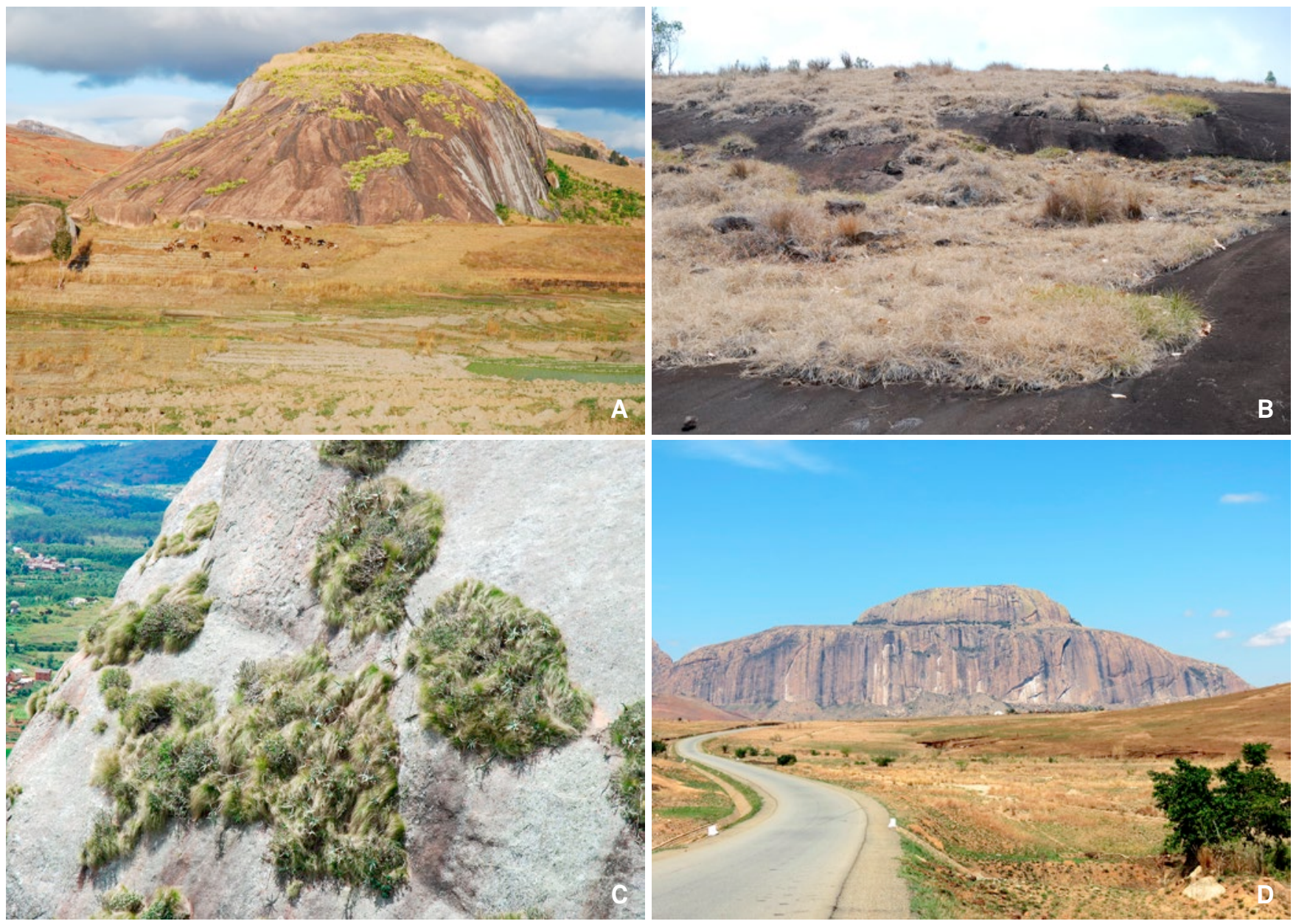

Fig. 6. - A. Inselberg, south of Anja Park (Tangorika) covered with Furcraea foetida (L.) Haw. (Asparagaceae);

B. Mat with Styppeiochloa hitchcockii (A. Camus) Cope (Poaceae) near Angavokely; C. Mats formed by Coleochloa setifera (Ridl.) Gilly

(Cyperaceae) and steep slopes, south of Fianarantsoa; D. General overview of "Bonnet du Pape, at Voatavo (Fig. 3: no 26).

[Photos: A-C: S. Porembski; D: R. Phillipson]

exceptions include those within certain National Parks such as Andringitra and Marojejy. In unprotected areas globally, inselbergs often support the last remnants of natural vegetation in a given area. While certain types of human use of inselbergs have occurred for generations and do not seem to have caused severe damage, in recent times human impact appears has become by far more destructive resulting in steadily growing pressure on these areas, and today most inselbergs in Madagascar exhibit detrimental human impacts. These include: the over-collection of certain useful species which impacts local populations or even threatens local endemics with extinction; use of inselbergs for grazing cattle and goats; uncontrolled bush-fires, usually resulting from the widespread burning of grasslands for agriculture, that may significantly impact the population of individual species and which are also responsible for habitat degradation or destruction as a whole (see Whitman et al., 2011 for a study of the influence of fire and water availability on the occurrence of orchids on Malagasy inselbergs); and quarrying, which results in the destruction of parts of, or even an entire inselberg, impacting available habitats as well as precipitation and water drainage patterns on and around the site (Fig. 8C). Secondary impacts following habitat degradation or destruction include the proliferation of invasive weeds, as our results show for Madagascar and as reported for other tropical regions in Porembs ki (2000). A particular danger to Malagasy inselbergs is the Neotropical Furcraea foetida which has invaded numerous inselbergs on the High Plateau (Fig. 6A), forming large populations by means of vegetative reproduction. This and other invasive species have negative impacts on any remaining pockets of more natural habitats and impede any natural regeneration as well as managed habitat restoration. Remarkably certain Malagasy inselberg endemics (notably certain species of Kalanchoe) have been introduced as ornamentals to other tropical regions where they have become invasive. 

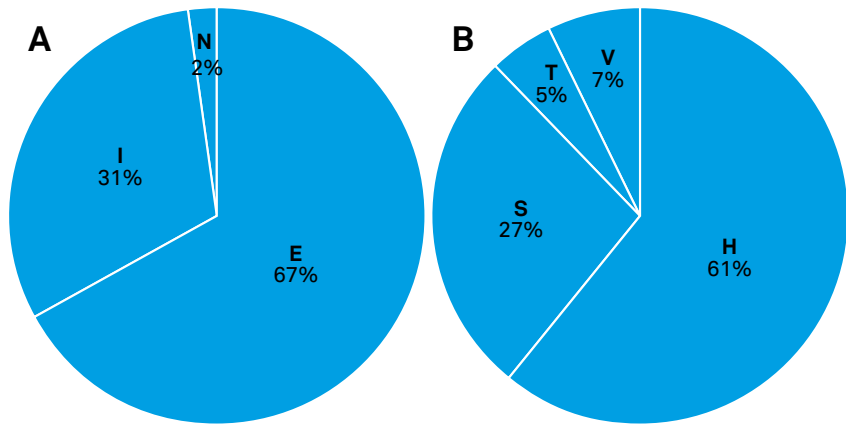

Fig. 7. - A. Distribution of Malagasy inselberg flora;

B. Life form diversity of Malagasy inselberg flora.

[Abbreviations: E, Endemic species; H, Herbs;

I, Indigenous non-endemic species; N, Naturalised species;

S, Shrubs; T, Trees; V, Vines and lianas]

The collection of useful plant species is particularly complex. In addition to plants used by local inhabitants for medicinal purposes that occur predominantly on inselbergs and that we observed in many local markets, such as Drosera madagascariensis (Fig. 5C), Myrothamnus moschatus, and the different species of Tetradenia Benth. and certain Aloe spp., the harvesting of Coleochloa setifera leaves, which are used to stuff mattresses, was observed, and they were seen for sale in local markets (Fig. 8D). While traditionally harvesting for local needs might have been undertaken at sustainable levels, with increased mobility of the population and potentially higher value of increasingly scarce resources, it seems probable that pressure on these species is probably on the increase. The collection of plants from inselbergs for ornamental purposes is a highly significant danger to inselberg habitats and biodiversity. This poses particular threats to succulent plants (e.g. species of Aloe and Pachypodium) and orchids which are sought after locally, nationally and internationally, they are commonly sold in local markets and are often illegally exported.

Some inselbergs in the southern part of Madagascar along National Route 7 have touristic importance and particular attention should be given for their protection. For example, inselbergs near Anja Park are managed and protected by the local community (Association AMI) in order to develop ecotourism. This site welcomes ca. 15,000 tourists per year. The money received from ecotourism contributes to the conservation of the local flora and fauna, as well as to the protection of the cultural heritage (e.g. tombs).

\section{Conclusions}

Building on the recent dramatic increase in the total surface area of Madagascar under formal protection for conservation (GARDNER et al., 2018), efforts are now underway to develop a coherent conservation strategy across the whole country that encompass the broadest range of habitats and as much of the country's extraordinary biodiversity. However, inselbergs have received little attention, and we hope that our study contributes to an increasing awareness of their importance, and that this ultimately results in their effective conservation and, where necessary, their restoration. Consequently, efforts are needed to extend the awareness to the population at large as well as the scientific community and decision-makers, and specifically to facilitate the human populations living nearby to take care of the inselbergs. The involvement of landholders in successful protection, restoration and monitoring of key landscape elements is the most effective way to reach this goal (BURKE, 2003a).

Further research on the flora and vegetation of inselbergs in Madagascar is needed. Prior to the current study, Malagasy inselbergs have been investigated in only a limited number of places on the seasonally dry Central High Plateau (Rauh, 1973; Fischer \& Theisen, 2000). Many inselbergs have escaped closer inspection, even those near the capital city of Antananarivo. Almost no information exists about inselbergs located in either the humid rainforests (except one in the Alaotra Mangoro Region: Andriambavimbe) or those in the Anosy Region in the south-east. Apart from basic inventory studies, molecular analysis is needed in order to understand patterns of population differentiation between isolated populations of individual species or species-complexes on inselbergs. Further studies, in addition to improving the knowledge base in these areas and better understanding evolutionary processes, also need to focus on species of economic value so that sustainable management practices can be established for these species and their habitats. The documentation of invasive species on inselbergs also needs to be improved so that effective eradication techniques can be developed, followed by the restoration of natural habitats. Few studies exist on the status of individual inselberg plant species, although a study of the carnivorous plant species Genlisea margaretae is being undertaken on an inselberg near Andranovelona in order to contribute to the long-term protection of this species.

Current studies are underway that aim toward a better understanding of dispersal processes between mainland Africa and Madagascar. Coleochloa setifera was chosen as a model species, since it is one of the most characteristic species on inselbergs both in East Africa and Madagascar. A similar approach could be applied to understand the phylogeography of Myrothamnus, which comprises two species that are strict inselberg specialists (M. moschatus in Madagascar and $M$. fabellifolius Welw. in East and South Africa). 

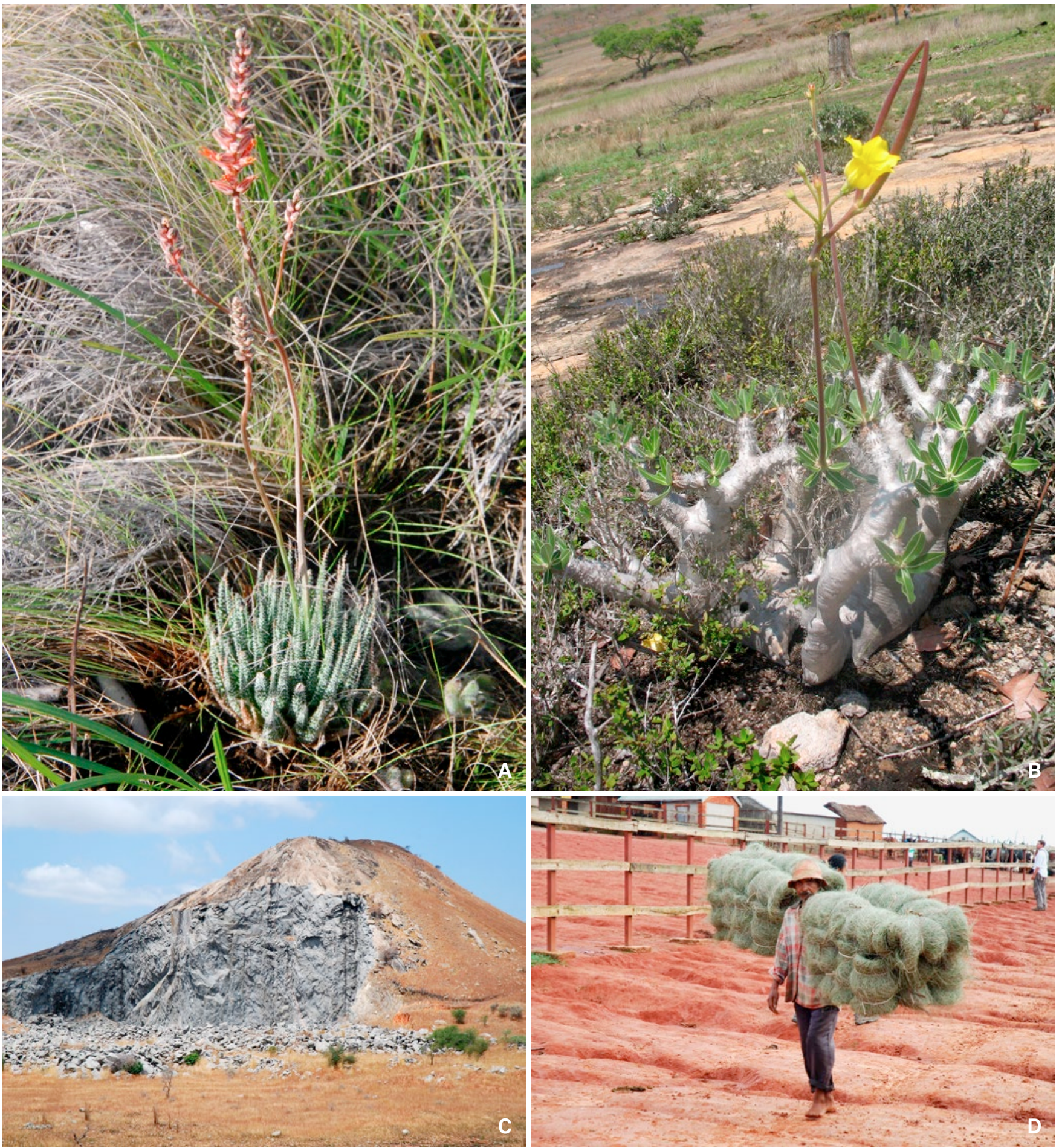

Fig. 8. - A. Aloe haworthioides Baker (Asphodelaceae); B. Pachypodium horombense Poiss. (Apocynaceae);

C. Quarry on an inselberg near Zazafotsy; D. Leaves of Coleochloa setifera (Ridl.) Gilly (Cyperaceae) sold at local market in Ambalavao.

[A: Razafindraibe et al. 293; B: Ramandimbisoa et al. 104] [Photos: A: C. Lebo; B-C: F. Rajaonary; D: S. Porembski] 


\section{Acknowledgements}

We thank Missouri Botanical Garden, especially the inselberg team (Roger Lala Andriamiarisoa, Cindy Frasier, Fano Rajaonary, Ando Ramahefaharivelo, Rondro Ramananjanahary, and Noro Ravololomanana), TAN herbarium, particularly Hanta Razafindraibe and Jacky Andriantiana for making the fieldwork successful and fun. We are also grateful to specialists who have accepted to identify most of the specimens collected, and Luc Etienne Guyot at Eau Vive, the bottled water company, for supporting research on the carnivorous plant Genlisea margaretae at Andranovelona. This work has been possible with support from Mellon Foundation through SANBI (South African National Biodiversity Institute) and by the Akademie der Wissenschaften und der Literatur Mainz, Germany. Finally, we thank Cindy Frasier and the two anonymous reviewers for making suggestions on an earlier version of this manuscript, Fano Rajaonary for compiling Figure 3 and Ando Ramahefaharivelo, Chad Lebo, Fano Rajaonary, Rebecca Phillipson, Sophie Giebelmann for permission to publish their pictures.

\section{References}

Battistini, R. \& J.-M. Hoerner (1986). Géographie de Madagascar. Sedes, Paris.

Bosser, J. (1958). Sur deux nouvelles Lentibularicées de Madagascar. Naturaliste Malgache 10: 21-29.

Burke, A. (2003a). Inselbergs in a changing world - global trends. Diversity E Distrib. 9: 375-383.

Burke, A. (2003b). The role of inselbergs in contributing to local and regional plant species richness. Biodivers. E Conservation 12: 469-486.

Callmander, M.W., P.B. Phillipson, G.E. Schatz, S. Andriambololonera, M. Rabarimanarivo, N. Rakotonirina, J. Raharimampionona, C. Chatelain, L. Gautier \& P.P. Lowry (2011). The endemic and non-endemic vascular flora of Madagascar updated. Pl. Ecol. Evol. 144: 121-125.

CITES (2019). Convention on International Trade in Endangered Species of Wild Fauna and Flora: Appendices I, II and III. [http:// www.cites.org/eng/app/appendices.php]

Fischer, E. \& I. Theisen (2000). Vegetation of Malagasy inselbergs. In: Porembski, S. \& W. Barthlott (ed.), Inselbergs. Biotic diversity of isolated rock outcrops in tropical and temperate regions. Ecol. Stud. 146: 259-276.

Fischer, E., S. Porembsiki \& W. Barthlott (2000). Revision of the genus Genlisea (Lentibulariaceae) in Africa and Madagascar with notes on ecology and phytogeography. Nordic J. Bot. 20: 291-318.

Gardner, C.J., M.E. Nicoll, C. Birkinshaw, A. Harris, R.E. Lewis, D. Rakotomalala \& A.N. Ratsifandrihamanana
(2018). The rapid expansion of Madagascar's protected area system. Biol. Conserv. 220: 29-36.

Gröger, A. (2000). Flora and vegetation of inselbergs of Venezuelan Guayana. In: Porembski, S. \& W. Barthlott (ed.), Inselbergs. Biotic diversity of isolated rock outcrops in tropical and temperate regions. Ecol. Stud. 146: 291-314.

Gröger, A. \& O. Huber (2007). Rock outcrop habitats in the Venezuelan Guayana lowlands: their main vegetation types and floristic components. Rev. Brasil. Bot. 30: 599-609.

IUCN (2012). Red List Categories and Criteria, version 3.1 ed 2. IUCN Species Survival Commission, Gland \& Cambridge.

Iwamura, T., K.A. Wilson, O. Venter \& H. P. Possingham (2010). A climatic stability approach to prioritizing global conservation investments. Plos One 5: e15103.

Madagascar Catalogue (2019). Catalogue of the Plants of Madagascar. Missouri Botanical Garden, St Louis \& Antananarivo. [http://www.tropicos.org/Project/MADA]

Newman, A. (2003). Madagascar Significant Trade - Plants. Report for CITES Secretariat. [https://http://www.cites.org/sites/ default/files/common/com/pc/13/X-PC13-08-inf.pdf ]

Porembsis, S. (1996). Notes on the vegetation of inselbergs in Malawi. Flora 191: 1-8.

Porembski, S. (2000). The invasibility of tropical granite outcrops (“inselbergs") by exotic weeds. J. Roy. Soc. Western Australia 83: 131-134.

Porembski, S. (2005). Floristic diversity of African and South American inselbergs: a comparative analysis. Acta Bot. Gall. 152: 573-580.

Porembski, S. (2006). Plants on tropical rock outcrops: adaptive strategies to harsh environmental conditions. In: TARAsIuk, J. \& J. Kepczynski (ed.), Czlowiek i srodowisko przyrodnicze Pomorza Zachodniego: 236-243. Uniwersytet Szczecinski.

Porembski, S. \& W. Barthlott (ed.) (2000a). Inselbergs. Biotic diversity of isolated rock outcrops in tropical and temperate regions. Ecol. Stud. 146.

Porembski, S. \& W. Barthlott (2000b). Inselbergs. Granitic and gneissic outcrops (inselbergs) as centers of diversity for desiccation-tolerant vascular plants. Pl. Ecol. 151:19-28.

Porembski, S. \& A. Watve (2005). Remarks on the species composition of ephemeral flush communities on paleotropical rock outcrops. Phytocoenologia 35: 389-401.

Porembski, S, G. Martinelli, R. Ohlemüller \& W. Barthlott (1998). Diversity and ecology of saxicolous vegetation mats on inselbergs in the Brazilian Atlantic rainforest. Diversity \& Distrib. 4: 107-119.

Porembs ki, S., U. Becker \& R. Seine (2000). Islands on islands: habitats on inselbergs. In: Porembski, S. \&W. Barthlott (ed.), 
Inselbergs. Biotic diversity of isolated rock outcrops in tropical and temperate regions. Ecol. Stud. 146: 49-67.

Rakotoarisoa, S.E., R.R. Klopper \& G.F. Smith (2014). A preliminary assessment of the conservation status of the genus Aloe L. in Madagascar. Bradleya 32: 81-91.

Rauh, W. (1973). Über die Zonierung und Differenzierung der Vegetation Madagaskars. Trop. Subtrop. Pflanzenwelt 1: 1-146.

RauH, W. (1995). Succulents and xerophytic plants of Madagascar. Vol. 1. Strawberry Press.

Seine, R., S. Porembs ki \&W. Barthlott (1995). A neglected habitat of carnivorous plants: inselbergs. Feddes Repert. 106: 555-562.

Seine, R., S. Porembski \& U. Becker (2000). Phytogeography. In: Porembski, S. \& W. Bart hlott (ed.), Inselbergs. Biotic diversity of isolated rock outcrops in tropical and temperate regions. Ecol. Stud. 146: 435-448.

TAylor, P. (1991). The genus Genlisea. Carniv. Pl. Newslett. 20: 20-35.

Twidale, C.R. (1981). Granitic inselbergs: domed, block-strewn and castellated. Geogr. J. (London) 147: 54-71.

UNEP-WCMC (2010). Étude du commerce important: espèces retenues par le Comité CITES pour les plantes conformément à la CoP14. Cambridge. [https://http://www.cites.org/sites/default/files/fra/ com/pc/19/f19-12-03-a3.pdf]

Whitman, M., M. Medler, J.J. Randriamanindry \& E. Rabakonandrianina (2011). Conservation of Madagascar's granite outcrop orchids: the influence of fire and moisture. Lankesteriana 11: 55-67.

Willis, K.J. (ed.) (2017). State of the World's Plants 2017. Royal Botanic Gardens, Kew. [https://stateoftheworldsplants.org/2017/ report/SOTWP_2017.pdf] 
Appendix I. List of species recorded during the present study that have IUCN risk of extinction assessments, arranged by family, with annotations of global distribution and threat category for each species (genera endemic to Madagascar in bold print).

[Abbreviations: CR = "Critically Endangered"; EN = "Endangered"; LC = "Least Concern"; NT = "Near Threatened"; VU = "Vulnerable"]

\begin{tabular}{|c|c|c|c|}
\hline Family & Taxon & Distribution & IUCN Cat. \\
\hline Anacardiaceae & Abrahamia buxifolia (H. Perrier) Randrianasolo \& Lowry & Madagascar & NT \\
\hline Anacardiaceae & Operculicarya hirsutissima Eggli & Madagascar & VU \\
\hline Apocynaceae & Catharanthus lanceus (Bojer ex A. DC.) Pichon & Madagascar & NT \\
\hline Apocynaceae & Catharanthus ovalis Markgr. & Madagascar & NT \\
\hline Apocynaceae & Catharanthus roseus (L.) G. Don & Madagascar & LC \\
\hline Apocynaceae & Craspidospermum verticillatum Bojer ex A. DC. & Madagascar & LC \\
\hline Apocynaceae & Ischnolepis graminifolia (Costantin \& Gallaud) Klack. & Madagascar & LC \\
\hline Apocynaceae & Mascarenhasia lisianthiflora A. DC. & Madagascar & LC \\
\hline Apocynaceae & Pachypodium densiflorum Baker & Madagascar & VU \\
\hline Apocynaceae & Pachypodium horombense Poiss. & Madagascar & VU \\
\hline Apocynaceae & Pachypodium lamerei Drake & Madagascar & VU \\
\hline Apocynaceae & Pentopetia urceolata Klack. & Madagascar & VU \\
\hline Apocynaceae & Secamone oleaefolia Decne. & Madagascar & LC \\
\hline Araliaceae & Polyscias ornifolia (Baker) Harms & Madagascar & LC \\
\hline Arecaceae & Ravenea glauca Jum. \& H. Perrier & Madagascar & VU \\
\hline Asteraceae & Helichrysum aphelexioides DC. & Madagascar & NT \\
\hline Asteraceae & Senecio canaliculatus Bojer ex DC. & Madagascar & VU \\
\hline Asteraceae & Senecio erechtitioides Baker & Madagascar & VU \\
\hline Asteraceae & Senecio hildebrandtii Baker & Madagascar & EN \\
\hline Asteraceae & Senecio leandrii Humbert & Madagascar & VU \\
\hline Asteraceae & Senecio mesembryanthemoides Bojer ex DC. & Madagascar & VU \\
\hline Asteraceae & Senecio quartziticolus Humbert & Madagascar & EN \\
\hline Balsaminaceae & Impatiens baronii Baker & Madagascar & LC \\
\hline Balsaminaceae & Impatiens lyallii Baker & Madagascar & LC \\
\hline Balsaminaceae & Impatiens rutenbergii O. Hoffm. & Madagascar & VU \\
\hline Bignoniaceae & Stereospermum euphorioides DC. & Madagascar & LC \\
\hline Cannabaceae & Trema orientalis (L.) Blume & Africa & LC \\
\hline Clusiaceae & Symphonia verrucosa (Planch. \& Triana) Benth. \& Hook. f. & Madagascar & VU \\
\hline Commelinaceae & Commelina africana var. mannii (C.B. Clarke) Brenan & Africa & LC \\
\hline Convolvulaceae & Ipomoea desmophylla Bojer ex Choisy & Madagascar & LC \\
\hline Convolvulaceae & Turbina bracteata Deroin & Madagascar & LC \\
\hline Cunoniaceae & Weinmannia lucens Baker & Madagascar & LC \\
\hline Cyperaceae & Bulbostylis hispidula (Vahl) R.W. Haines & Africa & LC \\
\hline Cyperaceae & Cyperus amabilis Vahl & Comoros, Australasia/Pacific, Africa, Asia, New World & LC \\
\hline Cyperaceae & Cyperus articulatus L. & Mascarenes, Seychelles, Australasia/Pacific, Africa, Asia & LC \\
\hline Cyperaceae & Cyperus cyperoides (L.) Kuntze & Comoros, Mascarenes, Australasia/Pacific, Africa & LC \\
\hline Cyperaceae & Cyperus dubius Rottb. & Comoros, Mascarenes, Seychelles, Africa, Asia & LC \\
\hline Cyperaceae & Fimbristylis dichotoma (L.) Vahl & Mascarenes, Australasia/Pacific, Africa & LC \\
\hline Cyperaceae & Fuirena umbellata Rottb. & Mascarenes, Australasia/Pacific, Africa, Asia, New World & LC \\
\hline Cyperaceae & Pycreus flavescens (L.) P. Beauv. ex Rchb. & Australasia/Pacific, Africa, Asia, Europe, New World & LC \\
\hline Dioscoreaceae & Dioscorea antaly Jum. \& H. Perrier & Madagascar & LC \\
\hline Dioscoreaceae & Dioscorea sansibarensis Pax & Naturalized in Madagascar & NT \\
\hline Dioscoreaceae & Dioscorea soso Jum. \& H. Perrier & Madagascar & LC \\
\hline
\end{tabular}




\begin{tabular}{|c|c|c|c|}
\hline Family & Taxon & Distribution & IUCN Cat. \\
\hline Dioscoreaceae & Tacca leontopetaloides (L.) Kuntze & Comoros, Africa & LC \\
\hline Droseraceae & Drosera indica L. & Australasia/Pacific, Africa & LC \\
\hline Ebenaceae & Diospyros myriophylla (H. Perrier) G.E. Schatz \& Lowry & Madagascar & LC \\
\hline Ericaceae & Vaccinium secundiflorum Hook. & Madagascar & LC \\
\hline Eriocaulaceae & Mesanthemum rutenbergianum Körn. & Madagascar & NT \\
\hline Euphorbiaceae & Euphorbia alluaudii Drake & Madagascar & LC \\
\hline Euphorbiaceae & Euphorbia antso Denis & Madagascar & LC \\
\hline Euphorbiaceae & Euphorbia didiereoides Denis ex Leandri & Madagascar & EN \\
\hline Euphorbiaceae & Euphorbia enterophora Drake & Madagascar & LC \\
\hline Euphorbiaceae & Euphorbia horombensis Ursch \& Leandri & Madagascar & EN \\
\hline Euphorbiaceae & Euphorbia imerina Cremers & Madagascar & EN \\
\hline Euphorbiaceae & Euphorbia milii Des Moul. & Madagascar & $\mathrm{DD}$ \\
\hline Euphorbiaceae & Euphorbia primulifolia Baker & Madagascar & VU \\
\hline Euphorbiaceae & Euphorbia rauhii Haevermans \& Labat & Madagascar & VU \\
\hline Euphorbiaceae & Euphorbia stenoclada Baill. & Comoros, Seychelles & LC \\
\hline Fabaceae & Alistilus jumellei (R. Vig.) Verdc. & Madagascar & VU \\
\hline Fabaceae & Crotalaria coursii M. Pelt. & Madagascar & NT \\
\hline Fabaceae & Crotalaria diosmifolia Benth. & Madagascar & VU \\
\hline Fabaceae & Crotalaria tanety Du Puy et al. & Madagascar & VU \\
\hline Fabaceae & Crotalaria uncinella Lam. & Mascarens, Africa & LC \\
\hline Fabaceae & Dalbergia greveana Baill. & Madagascar & LC \\
\hline Fabaceae & Indigofera bojeri Baker & Madagascar & LC \\
\hline Fabaceae & Indigofera mangokyensis R. Vig. & Madagascar & EN \\
\hline Fabaceae & Indigofera pedunculata Baker & Madagascar & NT \\
\hline Fabaceae & Microcharis phyllogramme (R. Vig.) Schrire et al. & Madagascar & LC \\
\hline Fabaceae & Mundulea stenophylla R. Vig. & Madagascar & LC \\
\hline Fabaceae & Ophrestia lyallii (Benth.) Verdc. & Madagascar & LC \\
\hline Fabaceae & Phylloxylon xiphoclada (Baker) Du Puy et al. & Madagascar & EN \\
\hline Fabaceae & Senna leandrii (Ghesq.) Du Puy & Madagascar & LC \\
\hline Fabaceae & Senna viguierella (Ghesq.) Du Puy & Madagascar & LC \\
\hline Fabaceae & Tetrapterocarpon geayi Humbert & Madagascar & LC \\
\hline Fabaceae & Vigna angivensis Baker & Madagascar & NT \\
\hline Fabaceae & Zornia puberula Mohlenbr. & Madagascar & LC \\
\hline Gentianaceae & Exacum exiguum Klack. & Madagascar & LC \\
\hline Gentianaceae & Exacum gracile Klack. & Madagascar & EN \\
\hline Gentianaceae & Exacum linearifolium (Humbert) Klack. & Madagascar & EN \\
\hline Gentianaceae & Exacum naviculare Klack. & Madagascar & EN \\
\hline Gentianaceae & Exacum spathulatum Baker & Madagascar & VU \\
\hline Gentianaceae & Exacum stenophyllum Klack. & Madagascar & EN \\
\hline Gentianaceae & Tachiadenus carinatus (Desr.) Griseb. & Madagascar & LC \\
\hline Gentianaceae & Tachiadenus gracilis Griseb. & Madagascar & NT \\
\hline Gentianaceae & Tachiadenus longiflorus Griseb. & Madagascar & NT \\
\hline Hypericaceae & Eliea articulata (Lam.) Cambess. & Madagascar & LC \\
\hline Iridaceae & Aristea kitchingii Baker & Madagascar & NT \\
\hline Iridaceae & Gladiolus bojeri (Baker) Goldblatt & Madagascar & NT \\
\hline Lamiaceae & Capitanopsis albida (Baker) Hedge & Madagascar & EN \\
\hline
\end{tabular}




\begin{tabular}{|c|c|c|c|}
\hline Family & Taxon & Distribution & IUCN Cat. \\
\hline Lamiaceae & Plectranthus bipinnatus A.J. Paton & Madagascar & VU \\
\hline Lamiaceae & Capitanopsis oreophila (Guillaumin) Mwanyambo et al. & Madagascar & EN \\
\hline Lamiaceae & Stachys brachiata Bojer ex Benth. & Madagascar & VU \\
\hline Lamiaceae & Stachys rubella Hedge & Madagascar & $\mathrm{CR}$ \\
\hline Lamiaceae & Tetradenia cordata Phillipson & Madagascar & VU \\
\hline Lamiaceae & Tetradenia goudotii Briq. & Madagascar & LC \\
\hline Lamiaceae & Tetradenia nervosa Codd & Madagascar & LC \\
\hline Lentibulariaceae & Genlisea margaretae Hutch. & Africa & $\mathrm{CR}$ \\
\hline Lentibulariaceae & Utricularia bisquamata Schrank & Africa & LC \\
\hline Lentibulariaceae & Utricularia livida E. Mey. & Africa & LC \\
\hline Lentibulariaceae & Utricularia prehensilis E. Mey. & Africa & LC \\
\hline Lentibulariaceae & Utricularia subulata L. & Africa & LC \\
\hline Malvaceae & Grewia nitida Juss. & Madagascar & EN \\
\hline Monimiaceae & Tambourissa purpurea (Tul.) A. DC. & Madagascar & LC \\
\hline Montiniaceae & Kaliphora madagascariensis Hook. f. & Madagascar & LC \\
\hline Moraceae & Ficus politoria Moon & Madagascar & LC \\
\hline Orchidaceae & Aerangis ellisii (B.S. Williams) Schltr. & Madagascar & LC \\
\hline Orchidaceae & Angraecum compactum Schltr. & Madagascar & LC \\
\hline Orchidaceae & Angraecum pseudofilicornu H. Perrier & Comoros & EN \\
\hline Orchidaceae & Angraecum rutenbergianum Kraenzl. & Madagascar & EN \\
\hline Orchidaceae & Angraecum setipes Schltr. & Madagascar & EN \\
\hline Orchidaceae & Angraecum sororium Schltr. & Madagascar & VU \\
\hline Orchidaceae & Bulbophyllum baronii Ridl. & Madagascar & LC \\
\hline Orchidaceae & Cynorkis baronii Rolfe & Madagascar & LC \\
\hline Orchidaceae & Cynorkis cinnabarina (Rolfe) Hermans \& P.J. Cribb & Madagascar & EN \\
\hline Orchidaceae & Cynorkis gibbosa Ridl. & Madagascar & LC \\
\hline Orchidaceae & Cynorkis gigas Schltr. & Madagascar & LC \\
\hline Orchidaceae & Cynorkis melinantha Schltr. & Madagascar & EN \\
\hline Orchidaceae & Cynorkis papillosa (Ridl.) Summerh. & Madagascar & EN \\
\hline Orchidaceae & Cynorkis perrieri Schltr. & Madagascar & EN \\
\hline Orchidaceae & Cynorkis uniflora Lindl. & Madagascar & LC \\
\hline Orchidaceae & Eulophia pileata Ridl. & Madagascar & EN \\
\hline Orchidaceae & Eulophia reticulata Ridl. & Madagascar & LC \\
\hline Orchidaceae & Gastrorchis francoisii Schltr. & Madagascar & VU \\
\hline Orchidaceae & Habenaria alta Ridl. & Madagascar & EN \\
\hline Orchidaceae & Habenaria ambositrana Schltr. & Madagascar & EN \\
\hline Orchidaceae & Habenaria hilsenbergii Ridl. & Madagascar & NT \\
\hline Orchidaceae & Habenaria simplex Kraenzl. & Madagascar & VU \\
\hline Orchidaceae & Habenaria truncata Lindl. & Madagascar & VU \\
\hline Orchidaceae & Jumellea intricata $\mathrm{H}$. Perrier & Madagascar & EN \\
\hline Orchidaceae & Jumellea jumelleana (Schltr.) Summerh. & Mascarenes & EN \\
\hline Orchidaceae & Jumellea maxillarioides (Ridl.) Schltr. & Comoros & EN \\
\hline Orchidaceae & Jumellea rigida Schltr. & Madagascar & VU \\
\hline Orchidaceae & Jumellea stenoglossa H. Perrier & Madagascar & EN \\
\hline Orchidaceae & Liparis anthericoides H. Perrier & Madagascar & VU \\
\hline Orchidaceae & Liparis bicornis Ridl. & Madagascar & EN \\
\hline
\end{tabular}




\begin{tabular}{|c|c|c|c|}
\hline Family & Taxon & Distribution & IUCN Cat. \\
\hline Orchidaceae & Liparis imerinensis Schltr. & Madagascar & EN \\
\hline Orchidaceae & Liparis listeroides Schltr. & Madagascar & EN \\
\hline Orchidaceae & Liparis longicaulis Ridl. & Madagascar & VU \\
\hline Orchidaceae & Liparis ochracea Ridl. & Madagascar & EN \\
\hline Orchidaceae & Oeceoclades beravensis (Rchb. f.) R. Bone \& Buerki & Madagascar & NT \\
\hline Orchidaceae & Oeceoclades calcarata (Schltr.) Garay \& P. Taylor & Madagascar & LC \\
\hline Orchidaceae & Oeceoclades pandurata (Rolfe) Garay \& P. Taylor & Madagascar & EN \\
\hline Orchidaceae & Oeceoclades perrieri (Schltr.) Garay \& P. Taylor & Madagascar & $\mathrm{CR}$ \\
\hline Orchidaceae & Orthochilus rutenbergianus (Kraenzl.) Bytebier & Madagascar & LC \\
\hline Orchidaceae & Polystachya perrieri Schltr. & Madagascar & $\mathrm{CR}$ \\
\hline Orchidaceae & Satyrium perrieri Schltr. & Madagascar & EN \\
\hline Orchidaceae & Satyrium rostratum Lindl. & Madagascar & VU \\
\hline Orchidaceae & Sobennikoffia humbertiana H. Perrier & Madagascar & LC \\
\hline Orchidaceae & Tylostigma foliosum Schltr. & Madagascar & EN \\
\hline Osmundaceae & Osmunda regalis $\mathrm{L}$. & Mascarenes, Africa, Asia, Europe, New World & LC \\
\hline Phyllanthaceae & Phyllanthus matitanensis Leandri & Madagascar & LC \\
\hline Phyllanthaceae & Uapaca bojeri Baill. & Madagascar & LC \\
\hline Piperaceae & Peperomia trichophylla Baker & Madagascar & VU \\
\hline Poaceae & Eragrostis stolonifera A. Camus & Madagascar & EN \\
\hline Poaceae & Paspalum scrobiculatum L. & Comoros, Australasia/Pacific, Africa, Asia, New World & LC \\
\hline Poaceae & Trichopteryx dregeana Nees ex Lindl. & Africa & LC \\
\hline Primulaceae & Lysimachia rubricaulis (Duby) U. Manns \& Anderb. & Madagascar & NT \\
\hline Rubiaceae & Chassalia bojeri Bremek. & Madagascar & LC \\
\hline Rubiaceae & Chassalia princei var. brachysepala Bremek. & Madagascar & LC \\
\hline Rubiaceae & Coffea buxifolia A. Chev. & Madagascar & LC \\
\hline Rubiaceae & Gardenia rutenbergiana (Baill. ex Vatke) J.-F. Leroy & Madagascar & LC \\
\hline Rubiaceae & Paederia grandidieri Drake & Madagascar & LC \\
\hline Rubiaceae & Paederia mandrarensis Homolle ex Puff & Madagascar & EN \\
\hline Rubiaceae & Pentanisia veronicoides (Baker) K. Schum. & Madagascar & VU \\
\hline Rubiaceae & Psychotria retiphlebia Baker & Madagascar & LC \\
\hline Rubiaceae & Saldinia aegialodes Bremek. & Madagascar & VU \\
\hline Rubiaceae & Tricalysia cryptocalyx Baker & Madagascar & LC \\
\hline Rubiaceae & Tricalysia dauphinensis Randriamb. \& De Block & Madagascar & VU \\
\hline Rutaceae & Vepris pilosa (Baker) I. Verd. & Madagascar & VU \\
\hline Sarcolaenaceae & Leptolaena pauciflora Baker & Madagascar & LC \\
\hline Sarcolaenaceae & Sarcolaena oblongifolia F. Gérard & Madagascar & LC \\
\hline Sarcolaenaceae & Xerochlamys bojeriana (Baill.) F. Gérard & Madagascar & LC \\
\hline Sarcolaenaceae & Xerochlamys tampoketsensis F. Gérard & Madagascar & VU \\
\hline Sphaerosepalaceae & Rhopalocarpus similis Hemsl. & Madagascar & LC \\
\hline Talinaceae & Talinella grevei Danguy & Madagascar & LC \\
\hline Vitaceae & Cayratia triternata (Baker) Desc. & Madagascar & LC \\
\hline Xyridaceae & Xyris labatii Rakotoar. et al. & Madagascar & LC \\
\hline
\end{tabular}

